\title{
PENGARUH SUBSTITUSI CEKER AYAM TERHADAP KUALITAS KIMIA NUGGET AYAM
}

\author{
Silviana rahayu ${ }^{1}$, Edy Susanto, S.Pt, MP $^{2}$, Eniswatin, S.Pd ${ }^{3}$ \\ 1) Program Studi Peternakan Fakultas Peternakan Universitas Islam Lamongan \\ 2) Fakultas Peternakan Universitas Islam Lamongan. \\ Jl.Veteran No.53.A Lamongan \\ E-mail: rahayusilvia83@gmail.com
}

\begin{abstract}
ABSTRAK
Ceker ayam (kaki ayam) merupakan bagian dari tubuh ayam yang kurang diminati oleh sebagian masyarakat, ceker ayam merupakan hasil samping dari pemotongan ayam dengan nilai harga yang lebih murah dibandingkan dengan hasil pemotongan bagian dari tubuh ayam lainnya. Selama ini ceker ayam baru dimanfaatkan secara konvensional oleh masyarakat sebagai campuran sop dan krupuk ceker ayam untuk penganekaragaman pangan penelitian kali ini menggunakan ceker ayam yang diisubstitusikan ke dalam nugget ayam. Telah dilakukan penelitian pada tanggal 9 April sampai 12 mei 2018 untuk mengetahui kualitas kimia nugget ayam yang disubstitusi dengan ceker ayam (shank) dari hasil limbah rumah potong ayam (RPA). Penelitian ini menggunakan rancangan acak lengkap (RAL) dengan 3 perlakuan dan 3 ulangan. Variabel yang diamati dalam kandungan kimia (kadar air, kadar lemak, kadar protein, kadar abu dan kadar karbohidrat) dari data yang didapat dianalisis menggunakan ANOVA. Hasil penelitian menunjukkan bahwa substitusi ceker ayam tidak berpengaruh nyata terhadap kadar air, kadar lemak,kadar abu, kadar protein dan kadar karbohidrat nugget ayam $(P<0,05)$. Hasil penelitian menunjukkan tidak adanya berbeda nyata hal ini dikarenakan kandungan ceker ayam tidak berbeda jauh dengan kandungan daging ayam.
\end{abstract}

Kata Kunci: ceker ayam, nugget, kualitas kimia nugget ayam.

\section{PENDAHULUAN}

Salah satu limbah (by product) yang dihasilkan dari rumah potong ayam (RPA) adalah ceker ayam (shank) dengan volume limbah cukup banyak. Data statistik peternakan tahun 2017 yang didapatkan dari data Dinas Peternakan Lamongan (2017) menunjukkan bahwa produksi daging ayam sebanyak 51.001 .892 ekor, bila berat ayam yang dipotong berkisar $2 \mathrm{~kg}$ maka jumlah ayam yang dipotong selama tahun 2017 adalah 102003784 (51.001.892x2) ekor dan jumlah potongan ceker ayam yang dihasilkan 51.001 .892 potong.

Ceker ayam (Shank) adalah suatu bagian dari tubuh ayam yang kurang diminati, yang terdiri atas komponen kulit, tulang, otot, dan kolagen sehingga perlu diberikan sentuhan teknologi untuk diolah menjadi produk yang memiliki nilai tambah. Selama ini ceker ayam baru dimanfaatkan secara konvensional oleh masyarakat sebagai campuran sop dan krupuk ceker ayam.

Dalam rangka penganekaragam pangan ceker ayam dan meningkatkan nilai ekonomisnya maka dilakukan pembuatan chicken nugget yang disubstitusi dengan ceker ayam. Dari produksi ceker 51.001 .892 potong tersebut akan menghasilkan produk nugget ayam substitusi ceker sekitar kurang lebih $637.523 \mathrm{~kg}$ nugget dengan demikian produk nugget yang dihasilkan dapat memenuhi permintaan para konsumen di sekitar daerah Lamongan.

Menurut Moedjiharto (2002) menyatakan bahwa nugget adalah produk olahan yang menggunakan teknologi restrukturisasi dengan memanfaatkan potongan daging yang relatif kecil yang tidak beraturan kemudian dilekatkan kembali menjadi ukuran yang lebih besar dibantu dengan bahan pengikat. Nugget dikonsumsi setelah proses penggorengan rendam (deep frying).

Untuk pembuatan bahan pangan baru harus memenuhi Standarisasi kualitas yang meliputi sifat kimia dan organoleptik. Persyaratan untuk menguji bahan pangan menurut BSN (2002) menggunakan uji kualitas kimia meliputi kadar lemak, air, abu, protein dan karbohidrat. Uji kualitas organoleptik meliputi aroma, rasa dan tekstur. Nugget memiliki standarisasi kualitas setelah memenuhiuji kualitas kimia, uji kualitas 
organoleptik dan persyaratan yang diajukan oleh BSN (2002).

\section{METODE}

Penelitian pada tahap pembuatan nugget ayam yang disubstitusi ceker ayam adalah eksperimental murni, sedangkan pada uji kualitas kimia adalah eksperimental semu dengan desain rancangan acak lengkap (RAL). Terdapat 3 (Tiga) perlakuan dengan 3 kali pengulangan. Penelitian dilaksanakan pada tanggal 9 April 2018 sampai 12 Mei 2018. Lokasi penelitian yang digunakan dalam pembuatan nugget yaitu bertempat di laboratorium Fakultas Peternakan Universitas Islam Lamongan dan untuk pengujian kualitas kimia dilakukan di Laboratorium pengujian Terpadu di Universitas Pembangunan Nasional "Veteran" Jawa Timur.

Tabel 1.1. Formula nugget ceker ayam

\begin{tabular}{lcccccc}
\hline $\begin{array}{l}\text { Bahan } \\
\text { baku }\end{array}$ & \multicolumn{2}{c}{$\mathrm{P} 0$} & \multicolumn{3}{c}{$\mathrm{P} 1$} & \multicolumn{2}{c}{$\mathrm{P} 2$} \\
\cline { 2 - 7 } $\begin{array}{l}\text { Daging } \\
\text { ayam }\end{array}$ & 500 & 66 & 375 & 50 & 250 & 3,3 \\
$\begin{array}{l}\text { Ceker } \\
\text { ayam }\end{array}$ & 0 & 0 & 125 & 16,6 & 250 & 33,3 \\
$\begin{array}{l}\text { Tepung } \\
\text { tapioka }\end{array}$ & 40 & 5,3 & 40 & 5,3 & 40 & 5,3 \\
$\begin{array}{l}\text { Garam } \\
\text { Lada }\end{array}$ & 2 & 0,27 & 2 & 0,27 & 2 & 0,27 \\
$\begin{array}{l}\text { Bawang } \\
\text { putih }\end{array}$ & 5 & 0,13 & 1 & 0,13 & 1 & 0,13 \\
Roti & 60 & 8 & 60 & 8 & 60 & 8 \\
$\begin{array}{l}\text { Telur } \\
\text { Tepung }\end{array}$ & 40 & 5,3 & 40 & 5,3 & 40 & 5,3 \\
$\begin{array}{l}\text { Panir } \\
\text { Total }\end{array}$ & 750 & 14,6 & 110 & 14,67 & 110 & 14,6 \\
\hline
\end{tabular}

Sumber : dari data hasil penelitioan (2018)

Variabel yang diamati adalah kualitas kimia yang meliputi : kadar air, kadar protein, kadar lemak, kadar karbohidrat dan kadar abu. Analisis kimia menggunakan nugget setengah matang. Data yang diperoleh dari hasil uji kadar lemak, kadar air, kadar protein, kadar karbohidrat dan kadar abu diolah dengan menggunakan analisis ragam atau ANOVA,

\section{HASIL DAN PEMBAHASAN Kualitas Kimia Nugget Ayam 1. Kadar Air}

Hasil pengujian kadar air nugget ayam substitusi ceker ayam dapat dilihat pada Tabel 1.2 Hasil analisis statistik menunjukkan bahwa nugget ayam substitusi ceker ayam yang berbeda tidak memberikan perbedaan yang nyata $(P>0,05)$ terhadap nilai kadar air.
Tabel 1.2. Rerata pengaruh substitusi ceker ayam pada kadar air nugget ayam.

\begin{tabular}{|c|c|c|c|c|}
\hline \multirow{2}{*}{$\begin{array}{l}\text { perlak } \\
\text { uan }\end{array}$} & \multicolumn{3}{|c|}{ Ulangan } & \multirow[t]{2}{*}{ Rerata } \\
\hline & 1 & 2 & 3 & \\
\hline P0 & 62,23 & 59,16 & 61,06 & 60,81 \\
\hline P1 & 60,62 & 60,63 & 60,03 & 60,43 \\
\hline P2 & 61,72 & 59,55 & 60,47 & 60,58 \\
\hline
\end{tabular}

menunjukkan tidak berbeda nyata $(p<0,05)$ terhadap kadar air nugget ayam yang disubstitusi dengan ceker ayam.

Berdasarkan Tabel 1.2 diatas menunjukkan bahwa rata-rata kadar air berkisar antara $60,43 \%$ sampai $60,81 \%$. Kadar air terendah terdapat pada perlakuan nugget dengan subtitusi ceker 25\% (P1), sedangkan kadar air tertinggi diperoleh dari perlakuan nugget dengan tanpa penambahan ceker (P0). Dengan demikian, kadar air nugget ayam yang disubtitusi ceker masih memenuhi standart kadar air yang telah ditetapkan oleh SNI No. 01-6683-2002 yaitu maksimum $60 \%$.

Widyastutik, dkk (2010) menyatakan bahwa kadar air nugget ayam disebabkan oleh banyak faktor misalnya meningkatnya kandungan bahan kering nugget ayam dan bahan pengisi. Komposisi bahan pangan terdiri atas bahan kering dan air. Kadar air suatu bahan pangan selain dipengaruhi oleh bahan baku, proses pengolahan juga akan mempengaruhi jumlah kadar air pada suatu produk.

Tabel 1.3 Hasil Anova Pengaruh substitusi ceker ayam pada kadar air nugget ayam

\begin{tabular}{|c|c|c|c|c|c|}
\hline Sk & $\mathrm{Db}$ & $\mathrm{Jk}$ & $\mathrm{Kt}$ & F hit & $\begin{array}{l}\mathrm{F} \\
\mathrm{Tab} \\
0,05\end{array}$ \\
\hline Perlakuan & 2 & 4,6 & 2,3 & 4,51 & 5,14 \\
\hline Galat & 6 & 3,04 & 0,51 & & \\
\hline Total & 8 & 7,64 & & & \\
\hline
\end{tabular}

Berdasarkan hasil data statistik dengan perbedaan penambahan bahan baku dengan ceker ayam dengan menggunakan a 0,05 pada taraf signifikan diperoleh $p$-value $4,51<5,14$ sehingga dapat disimpulkan bahwa perbedaan level penambahan ceker ayam tidak berpengaruh nyata. Hal ini dikarenakan kadar air antara daging ayam dan ceker berada pada kisaran yang sama yaitu daging ayam 65,95\% (stadelman, et.al., 1988 dalam Suradi 2006) dan ceker ayam menurut 
(Purnomo,1992:Miwada dan Simpen, 2007), sehingga dengan penambahan ceker ayam pada adonan maka kadar airnya tidak berbeda begitu nyata.

\section{Kadar Abu}

Bahan pangan selain mengandung bahan organik dan air juga mengandung mineral atau bahan-bahan anorganik. Abu merupakan bahan anorganik yang tidak terbakar pada proses pembakaran, abu dapat diartikan sebagai elemen mineral bahan. Fungsi mineral bagi tubuh manusia adalah sebagai zat pengatur dan pembangun ( Winarno, 2004 ).

Tabel 1.4. Hasil Anova Pengaruh substitusi ceker ayam pada kadar abu nugget ayam

\begin{tabular}{llllll}
\hline Sk & Db & Jk & Kt & $\begin{array}{l}\text { F. } \\
\text { hit }\end{array}$ & $\begin{array}{l}\text { F. } \\
\text { Tab }\end{array}$ \\
\hline Perlakuan & $\mathbf{2}$ & 0,24 & 0,12 & 0,75 & 5,14 \\
Galat & $\mathbf{6}$ & 0,93 & 0,16 & & \\
Total & $\mathbf{8}$ & 1,17 & & & \\
\hline
\end{tabular}

Sumber : dari data primer yang diolah (2018)

Berdasarkan Tabel 1.4 hasil hitung dan statistik menghasilkan $F$ hitung didapatkan hasil bahwa tidak terdapat perbedaan nyata $(\mathrm{P}<0,05)$ dan $\mathrm{HO}$ diterima pada nugget ayam yang disubtitusi dengan ceker ayam. Hal ini dikarenakan setiap perlakuan dari pembuatan nugget menggunakan bahan pengisi yang sama dan dalam jumlah yang sama, yang membedakan hanya jumlah dari penambahan bahan baku utamanya sehingga kadar abu pada perlakuan nugget tidak berbeda nyata. Kadar abu ceker ayam 3,4\% (Purnomo, 2000) sehingga tidak dapat meningkatkan kadar abu nugget ayam. Hal ini dikarenakan persentasase penggunaan daging ayam $33,3 \%$ dan ceker ayam 33,3\% dari total bahan. Hasil penelitian tersebut mengidikasikan bahwa substitusi ceker ayam tidak merubah mutu abu protein nugget ayam, sehingga layak untuk dijadikan salah satu bahan penambahan nugget ayam yang berkualitas.

\section{Kadar Protein}

Menurut Winarno (1997) protein merupakan zat makanan yang sangat penting bagi tubuh karena berfungsi sebagai bahan bakar, zat pembangun dan zat pengatur tubuh.
Tabel 1.5 Hasil Anova Pengaruh substitusi ceker ayam pada kadar protein nugget ayam

\begin{tabular}{llllll}
\hline Sk & Db & Jk & Kt & $\begin{array}{l}\text { F. } \\
\text { hit }\end{array}$ & $\begin{array}{l}\text { F. } \\
\text { Tab }\end{array}$ \\
\hline Perlakuan & 2 & 0,44 & 0,22 & 0,28 & 5,14 \\
Galat & 6 & 4,69 & 0,78 & & \\
Total & 8 & 5,13 & & & \\
\hline
\end{tabular}

Sumber : dari data primer yang diolah (2018)

Berdasarkan hasil data statistik dengan yang ditunjukkan oleh Tabel 1.5 perbedaan penambahan bahan baku dengan ceker ayam dengan menggunakan a 0,05 pada taraf signifikan diperoleh p-value 0,28<5,14 sehingga dapat disimpulkan bahwa perbedaan level penambahan ceker ayam tidak berpengaruh nyata. Hal ini disebabkan kadar protein antara daging ayam dan ceker berada pada kisaran yang sama yaitu daging ayam 18-22\% (Dirjen 2001) dan ceker ayam $22 \%$ menurut (Purnomo,1992:Miwada dan Simpen, 2007), sehingga dengan penambahan ceker ayam pada adoanan maka kadar proteinnya tidak berbeda begitu nyata.

Dari hasil penelitian yang telah dilakukan dapat diartikan bahwa substitusi ceker ayam tidak merubah dari mutu protein nugget ayam, sehingga layak untuk dijadikan salah satu penambah nugget ayam yang berkualitas dan sudah memenuhi kadar protein standart mutu nugget (SNI 6683-2014), yaitu minimal 12\%.

\section{Kadar Lemak}

Lemak dan minyak merupakan sumber energi yang efektif dan juga salah satu zat makanan penting yang berperan dalam kesehatan manusia (Winarno, 2004). Lemak dalam bahan pangan berfungsi untuk memperbaiki rupa dan struktur fisik bahan pangan, menambahkan nilai gizi serta memberikan cita rasa gurih pada bahan pangan.

Tabel 1.6 Hasil Anova Pengaruh substitusi ceker ayam pada kadar lemak nugget ayam

\begin{tabular}{ccccc|l}
\hline Sk & Db & Jk & Kt & F.hit & F Tab \\
\cline { 5 - 6 } & & & & & $\mathbf{0 , 0 5}$ \\
\hline Perlakuan & $\mathbf{2}$ & 0,54 & 0,27 & 0,35 & 5,14 \\
Galat & $\mathbf{6}$ & 4,35 & 0,73 & & \\
Total & $\mathbf{8}$ & 4,89 & & & \\
\hline
\end{tabular}


Sumber :data primer yang diolah (2018)

Hasil penelitian yang telah dilakukan mengindikasikan bahwa substitusi ceker ayam tidak merubah mutu lemak nugget ayam, sehingga layak untuk dijadikan salah satu bahan penambahan nugget ayam yang berkualitas. Kadar lemak nugget ayam pada perbedaan penambahan bahan baku substitusi ceker ayam dengan menggunakan a 0,05 pada taraf signifikan diperoleh $p$-value $(0,35<5,14)$, sehingga dapat disimpulkan bahwa perbedaan level penambahan ceker ayam tidak berpengaruh nyata. Perbedaan level penambahan ceker ayam $0 \%, 25 \%$,dan $50 \%$ tidak berpengaruh nyata terhadap komposisi lemak nugget, artinya dalam pengambilan keputusan penilaian nugget ceker ayam menggunakan pertimbangan selain kadar lemak.

\section{Kadar Karbohidrat}

Karbohidrat memiliki peranan penting dalam menentukan karakteristik bahan makanan misalnya rasa, warna, tekstur dan lainnya. Sedangkan untuk tubuh karbohidrat berguna untuk mencegah timbulnya ketosis, pemecahan protein dalam tubuh berlebihan, kehilangan mineral dan berguna untuk membantu metabolisme lemak dan protein (Winarno, 2008).

Tabel 4.13 Hasil Anova Pengaruh substitusi

\begin{tabular}{lcccccc} 
& \multicolumn{2}{c}{$\begin{array}{c}\text { ceker } \\
\text { karbohidrat }\end{array}$ nugget ayam } & kadar \\
\hline Sk & Db & Jk & Kt & F.hit & $\begin{array}{l}\text { F. } \\
\text { Tab }\end{array}$ \\
\cline { 3 - 6 } & & & & & $\mathbf{0 , 0 5}$ \\
\hline Perlakuan & $\mathbf{2}$ & 0,33 & 0,17 & 0,037 & 5,14 \\
Galat & $\mathbf{6}$ & 27,52 & 4,59 & & \\
Total & $\mathbf{8}$ & 27,85 & & & \\
\hline
\end{tabular}

Sumber : Data primer yang diolah (2018)

Kadar karbohidrat nugget ayam dengan perbedaan prosentase penambahan bahan baku ceker ayam tidak berpengaruh nyata $(p<0,05)$. Kadar karbohidrat pada nugget ayam tidak berbeda nyata hal ini dikarenakan nugget yang disubtitusi dengan ceker ayam, kandungan karbohidratnya berasal dari karbohidrat bahan pengisi yaitu tepung terigu dan roti, sedangkan komposisi bahan pengisi tersebut dalam setiap perlakuan komposisinya sama sehingga kadar karbohidrat pada tiap perlakuan nugget tidak berbeda nyata.Karbohidrat pada ayam terdapat pada golongan polisakarida yang berbentuk glikogen yang terserap dalam otot ayam dengan jumlah 5 gram dalam 100 gram daging.

\section{KESIMPULAN}

Berdasarkan hasil penelitian yang dilakukan dapat disimpulkan bahwa subtitusi ceker ayam tidak memberikan perbedaan pengaruh yang nyata $(\mathrm{P}<\mathrm{O}, \mathrm{O} 5)$ terhadap kadar air, protein, lemak, karbohidrat dan abu pada nugget ayam. Hal ini berarti substitusi ceker tidak merubah mutu kualitas kimia nugget ayam sampai pada taraf $50 \%$ ceker ayam dan $50 \%$ daging ayam.

\section{DAFTAR PUSTAKA}

Badan Standarisasi Nasional . 2002. Nugget ayam. SNI 01-6683. Badan Standarisasi Nasional, Jakarta.

Dinas peternakan Lamongan (2018).

Direktoral Jendral Peternakan. 2001. Departemen Pertanian dan Peternakan. Basis data Statistik. http://www.Deptan.com

Miwada, I. N. S. Dan I. N. Simpen. 2007. Optimalisasi Potensi ceker aya (shank) hasil limbah RPH melalui metode ekstraksi termodifikasi untuk menghasilkan gelatin. Skripsi Jurusan Produksi ternak. Fakultas Peternakan, Universitas Udayana, Denpasar. Moedjiharto, T.J. 2002. Usaha Industri Rumah Tangga Fish Nugget. Laboratorium IImu dan Teknologi Pangan Fakultas Teknologi Hasil Pertanian. Universitas Brawijaya. Malang.

Purnomo, H., D. Amertaningtyas, dan Siswanto. 2000. Pembuatan Chicken Nugget dengan Konsentrasi Tepung Tapioka dan Lama Pemasakan yang Berbeda. Prosiding Seminar Nasional Industri Pangan. Perhimpunan Ahli Teknologi Pangan Indonesia. Bogor.

SNI. 2014 Standart Nasional Indonesia SNI 06683-2014 Naget Ayam (chicken Nugget). Badan Standarisasi Nasional. Jakarta.

Suradi. K. 2006. PerubahanSifat fisik daging ayam broiler post mortem selama penyimpanan temperatur ruang(change of physical characteristics of Broiler Chickeen 
meatpost mortem during room temperatur storage), jurnal, Fakultas Peternakan, Universitas Padjajaran. Bandung.

Widyastuti, E.S., A.S.Widati, R.D. Hanjariyanto, dan M.Y.Avianto.2010. Kualitas Nugget Ayam dengan Penambahan Keju Gouda. Jurnal IImu dan teknologi Hasil Ternak. 5(1): 1-10

Winarno, F.G. 1997. Kimia Pangan dan Gizi. PT. Gramedia Pustaka Utama, Jakarta.

Winarno, F.G.2004. Kimia Pangan dan Gizi. P.T. Gramedia Pustaka Utama. Jakarta.

Winarno, F.G. 2008. Kimia Pangan dan Gizi. PT. Gramedia Pustaka Utama, Jakarta 